\title{
"HADES" - A REMARKABLE CAVE ON OLDOINYO LENGAI IN THE EAST AFRICAN RIFT VALLEY
}

\author{
Gordon J. Davies
}

\begin{abstract}
Oldoinyo Lengai is the world's only active carbonatite volcano, situated in northern Tanzania within the Eastern Rift Valley, at 2.751 degrees S, 35.902 degrees E. It forms an isolated symmetrical cone at the southern end of Lake Natron, with a summit elevation of 2,890 m ( 9,480 ft). Periodic eruptions of ash and lava have been recorded since about 1880, and with increasing precision during this century since 1904. In 1990 a routine expedition to monitor activity levels at the summit led to the discovery of a remarkable cave located in the crater floor, filled with numerous long delicate pale yellow stalactites and stalagmites of unknown composition. Within $100 \mathrm{~m}$ there was considerable volcanic activity taking place, and black lava was spraying from a small cone at a height of some $10 \mathrm{~m}$ above the crater floor. Due to the regular emission of lava at the summit of Lengai, it is unlikely that the cave could have survived intact for more than a few months at most. High internal temperatures and lack of safe access precluded any attempt at entry and sampling of the very unusual and attractive formations within the cave, but a good photographic record was obtained.
\end{abstract}

Keywords: speleothems, volcanic caves, Tanzania

\section{INTRODUCTION}

This paper is based on a brief presentation made by the author to the $8^{\text {th }}$ International Symposium on Vulcanospeleology held in Nairobi, Kenya, on $7 / 8^{\text {th }}$ February 1998. This described an unusual and spectacular cave located on the crater floor of Oldoinyo Lengai (translating as "the Mountain of God" from the Maasai language), an active carbonatite volcano situated in Northern Tanzania in an isolated section of Eastern (or Gregory) Rift Valley. The cave was discovered and photographed during an expedition led by Professor Celia Nyamweru in August 1990, which was one of a series of visits to monitor and record volcanic activity within the summit crater.

\section{LOCATION AND GEOLOGY}

The Eastern branch of the Great Rift Valley (known in its central section as the Gregory Rift) is part of a complex graben structure of great geological interest which extends more than an eighth of the way round the globe, and is associated with considerable volcanic and geothermal activity. The system becomes particularly highly developed and visually impressive in Tanzania and Kenya, although the Rift can be traced from Malawi as far north as Syria. The East African section is characterised by numerous extinct volcanoes and by lakes, many of which are alkaline to a greater or lesser extent. Kenya in particular is also noted for extensive and complex lava tubes both within the Rift (e.g. Suswa with c 40 caves total length $11+\mathrm{km}$ ) and close to its eastern

\footnotetext{
* Cave Exploration Group of East Africa.
} 


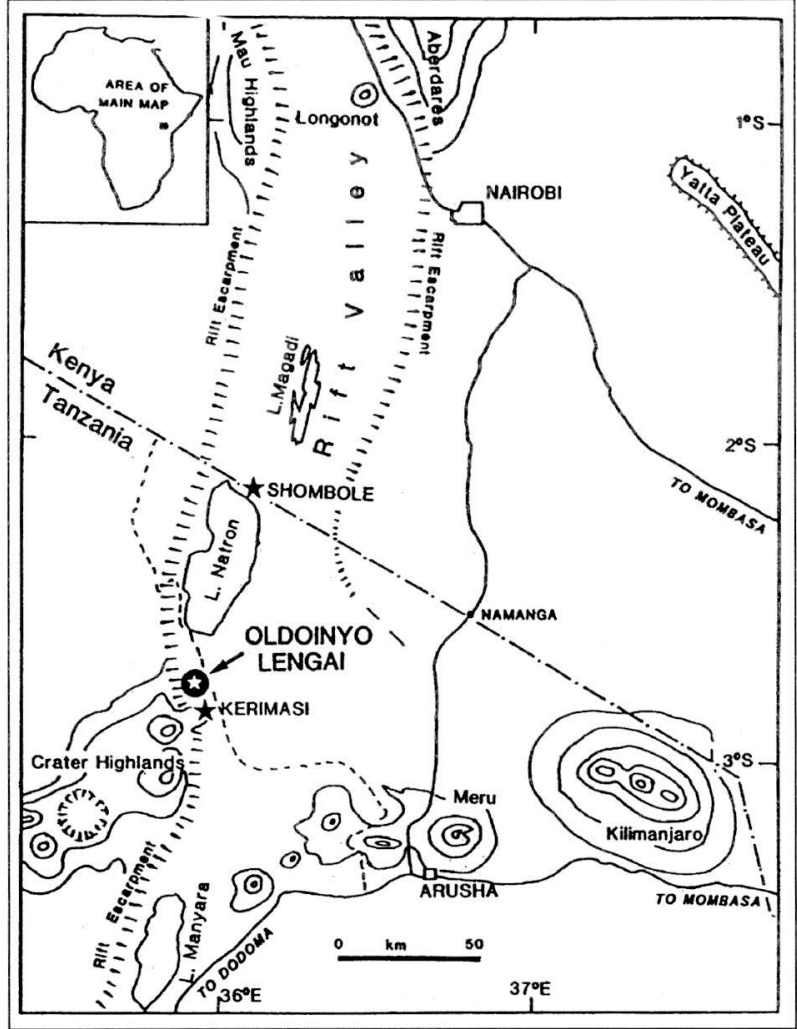

Fig. 1 - Location map for Oldoinyo Lengai.

edge e.g. Leviathan Cave total length c $12.5 \mathrm{~km}$ in the Chyulu Hills (Sutcliffe 1973, Simons 1998).

The author spent a total of 8 years based at Lake Magadi (110 km SW of Nairobi) which contains c 100 million tonnes of trona, or sodium sesquicarbonate, a mixture of sodium carbonate and bicarbonate, with significant quantities of sodium chloride and fluoride also present. Lake Magadi lies $95 \mathrm{~km}$ NNE of Lengai, just across the Kenya border and is an important commercial source of pure sodium carbonate (c 250,000 tonnes per annum) used mainly for glass manufacture.

South of Magadi lies a far bigger alkaline deposit, Lake Natron, which, from satellite photographs, was probably once part of one vast alkaline deposit or lake stretching from Lengai to north of Magadi, with the extinct volcano Shombole lying in between on the current Kenya/Tanzania border. Lengai's periodic major eruptions have undoubtedly contributed to the existing alkaline deposits. However it is likely that the majority of the material has accumulated via numerous hot alkaline springs which emerge all round the shores of Lakes Natron and Magadi and evaporate in the hot, dry atmosphere. For most of the year the summit of Oldoinyo Lengai is clearly visible from Magadi and major eruptions can be identified. With the aid of the Mountain Club of Kenya an unofficial four wheel drive track was opened up from Magadi during the '60's along the shore of Lake Natron to Lengai, making one day ascents possible during a (long) weekend from Nairobi (Davies, 1968). In recent years Lengai has had to be approached via northern Tanzania. 
In the vicinity of Lengai are several ancient, inactive, volcanoes including Shombole, Gelai, Kerimasi and the world famous Ngorongoro Crater with a caldera some 19 $\mathrm{km}$ in diameter (Fig 1). Most have been quite thoroughly explored and no caves have been reported. The last major faulting in this area was about 1.2 Ma ago. Lengai is the most recent of the group of nepheline-phonolite-carbonatite volcanoes which post-date this faulting, and is at most some 370,000 years old .Historical activity has consisted of small tephra eruptions and emission of numerous natrocarbonatite lava flows on the floor of the summit crater.

Fig. 2 - Sketch of "Hades" Cave on Oldoinyo Lengai.

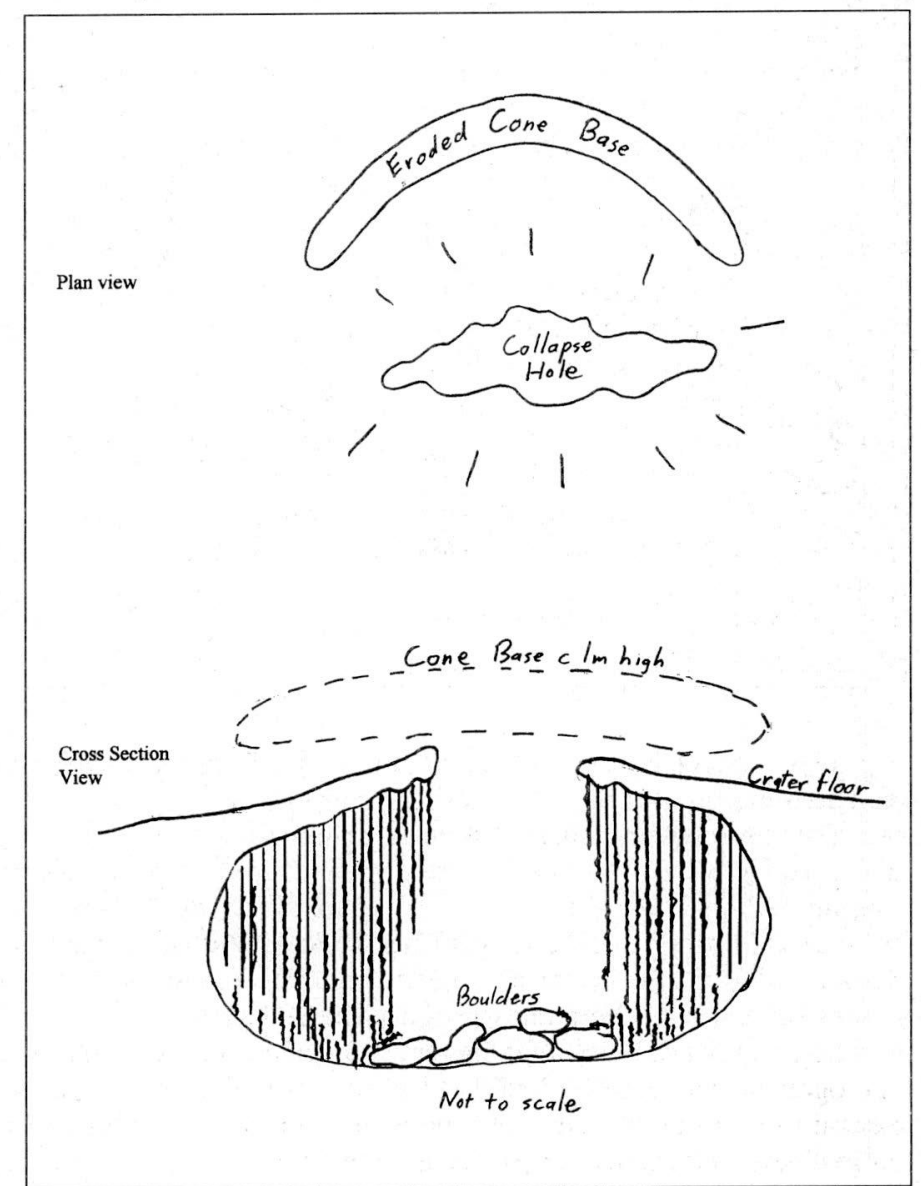

\section{RECENT ACTIVITY ON OLDOINYO LENGAI}

Lengai is now the only active volcano in the Gregory Rift Valley, and has been well known to the Maasai tribe, who inhabit this region, for many centuries. Periodic major ash eruptions have destroyed extensive areas of grazing and even killed the tribe's livestock on occasion. There are well documented records of major periodic activity com- 
mencing in 1904, with major ash eruptions in 1917, 1926 (visible from Magadi) and 1940-41 (Richard, 1942). Lava extrusions occurred between 1958 and 1966, when a major ash eruption also took place. The author took part in a routine Mountain Club of Kenya expedition which reached the summit of Lengai on Sunday $7^{\text {th }}$ August 1966, and descended about $100 \mathrm{~m}$ to the crater floor. During this visit there was considerable activity, with black lava being ejected into the air at several locations. Boiling lava pits were also present but no caves were observed. On the following Tuesday, $9^{\text {th }}$ August, an East African Airways pilot reported seeing an ash plume above Lengai reaching a height of about $4000 \mathrm{~m}$. Thus the expedition narrowly escaped, by only a few hours, witnessing a major volcanic eruption at disconcertingly close quarters, which could have spoiled their entire day.

After a quiescent period activity resumed in 1983, characterised by considerable effusion of lava within the crater. In December 1985 a party led by Bill Waldron (Waldron, 1998) observed a number of unusual features within the summit crater on Lengai, apparently created by a substantial fall in the level of the underlying molten lava. These included major faults in the crater levels, including short tunnels, a collapse hole and one small tube partially blocked by a secondary flow (Fig. 2, Fig. 3-5). In addition he discovered small groups of stalactites (c $50 \mathrm{~cm}$ long) fringing a small cave (Fig. 6-8) and recorded examples of elaborate secondary mineral deposits on the crater wall above the cave and on the crater floor (Fig. 9).

On many occasions, including the 1990 expedition featured in this paper, molten lava ponds and emissions from small parasitic cones have been observed, and the crater floor level has risen as lava has flowed out across it. Some flows on Lengai in the past have been measured as the most mobile of any terrestrial lavas (Dawson et al., 1990), whilst others have been exceptionally viscous (Dawson et al., 1994, Nyamweru, 1997). Spasmodic activity within Lengai's crater has continued up to early 1998, with periodic flows of new black aa pahoehoe lave flows, many being tube fed, from tubes between 10 and $150 \mathrm{~m}$ long. Considerable variations in lava levels have been observed, with a chimney $30 \mathrm{~m}$ deep in one instance and a lava pond level which dropped leaving solid lava "stalactites" on the walls.

A most interesting and detailed account of the historic and recent activity of Lengai may be found in a paper publisched by Springer-Verlag (Dawson et al., 1995), which also contains a large number of valuable references.

\section{DISCOVERY OF THE CAVE}

In August 1990 the author joined a small expedition to ascend Lengai and camp inside the crater on the summit. This was organised by Celia Nyemweru, who has made a comprehensive geological study of the mountain over a number of years, including numerous visits to the summit to record activity levels and changes in topography. Lengai forms a perfect isolated cone, at the angle of repose of ash and possible earlier lava flows from the summit, rising from the shores of Lake Natron which lies at an altitude of c $610 \mathrm{~m}(2,000 \mathrm{ft}$.). Depending on recent activity, its flanks may be covered in pale grey or whitish alkaline dust deposits, or by the remarkably hardy vegetation which rapidly re-establishes itself within a few years of a major eruption. The cone is also eroded by vertical rain gullies which have cut deep into the lower sections of consolidated ash, forming narrow canyons crossed by natural bridges in some places. An ascent of the volcano is not lightly undertaken, as the steep and unprotected slope is unremitting for some $2,000 \mathrm{~m}$. When the vegetation has been destroyed by recent activ- 


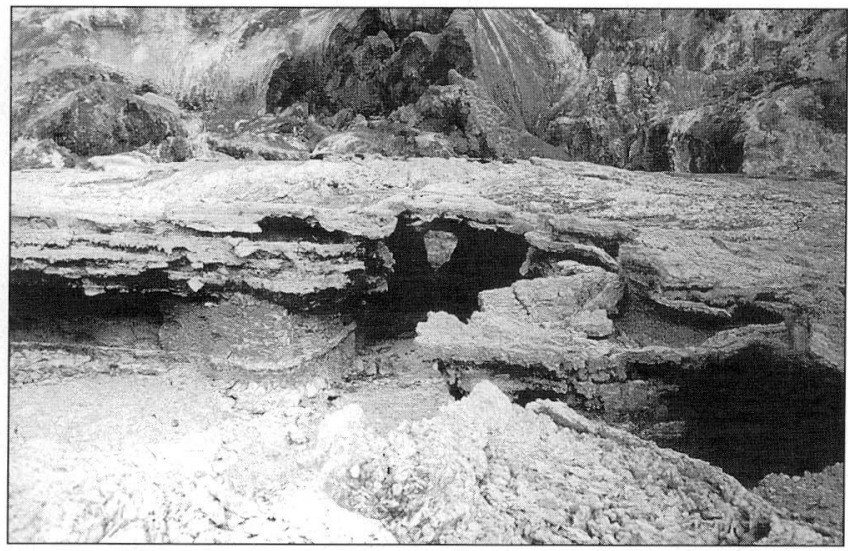

Fig. 3 - Crater floor with tunnel (December 1985) - Photo by Bill Waldron.

Fig. 4 - Pit in crater floor (December 1985) - Photo by Bill Waldron.
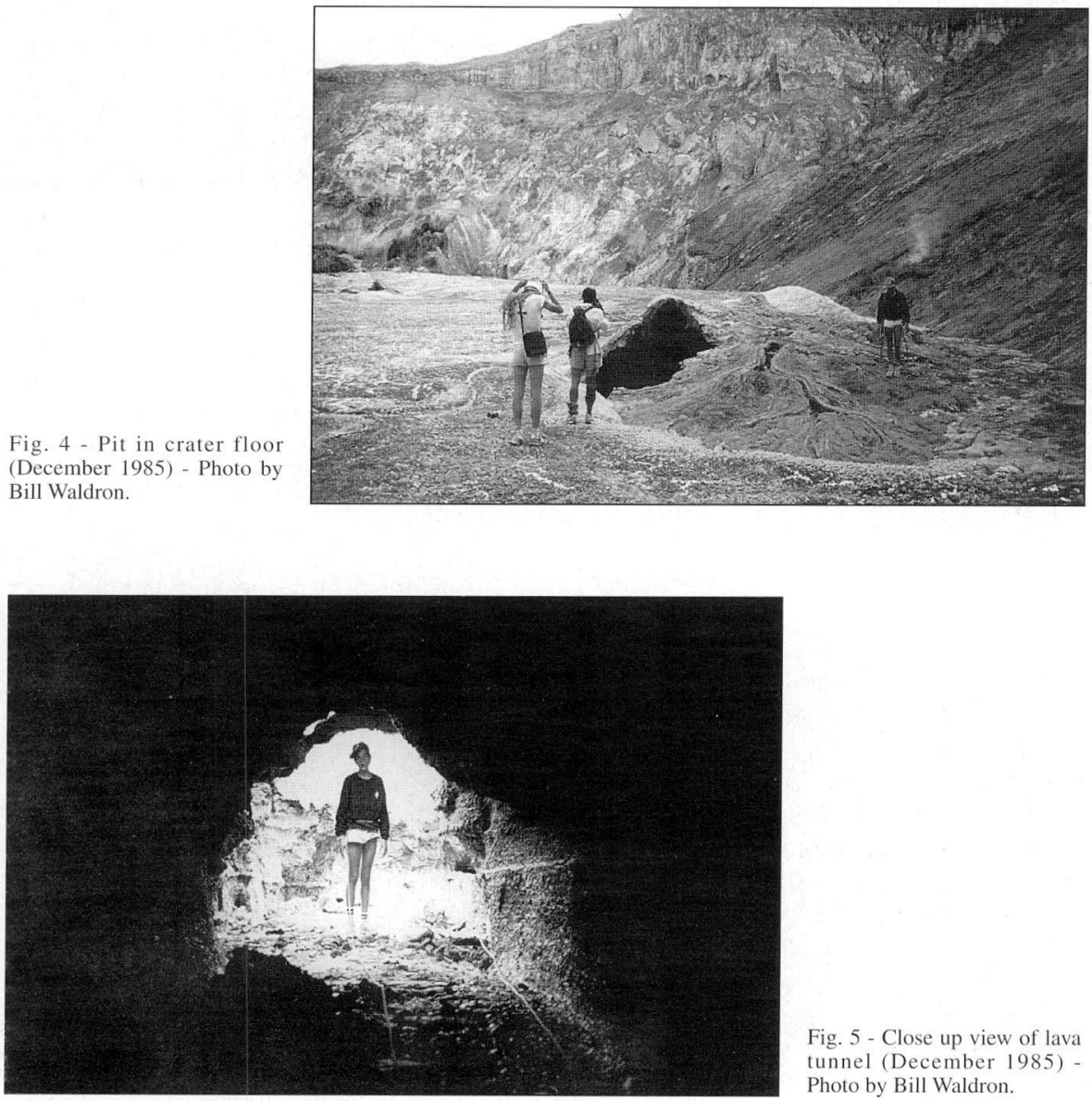

Fig. 5 - Close up view of lava tunnel (December 1985) Photo by Bill Waldron. 


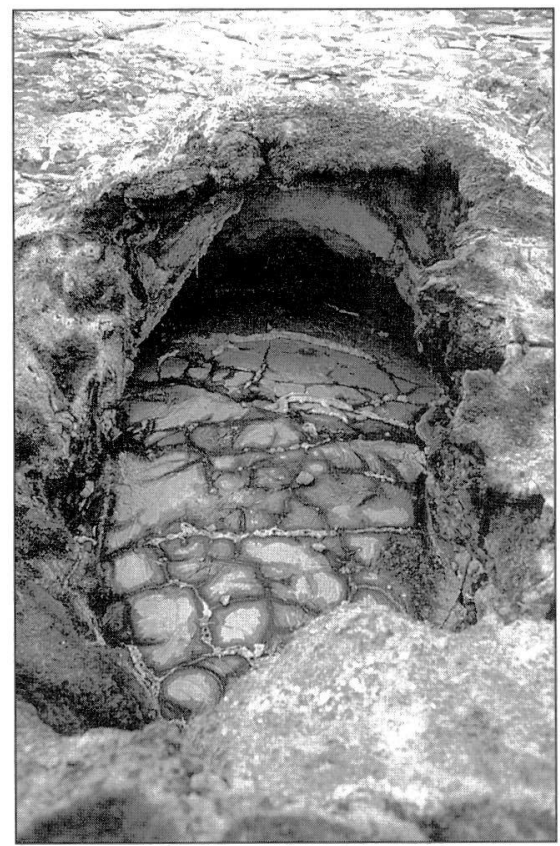

Fig. 6 - Small cave with secondary flow (c. $1.5 \mathrm{~m}$ wide) (December 1985) - Photo by Bill Waldron.

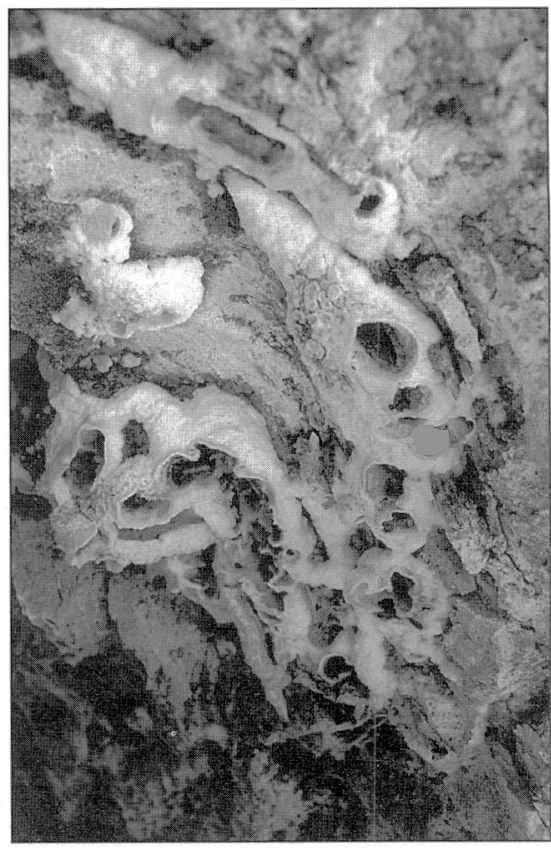

Fig. 7 - Close up of tubular secondary mineral deposits on cave wall (December 1985) - Photo by Bill Waldron.

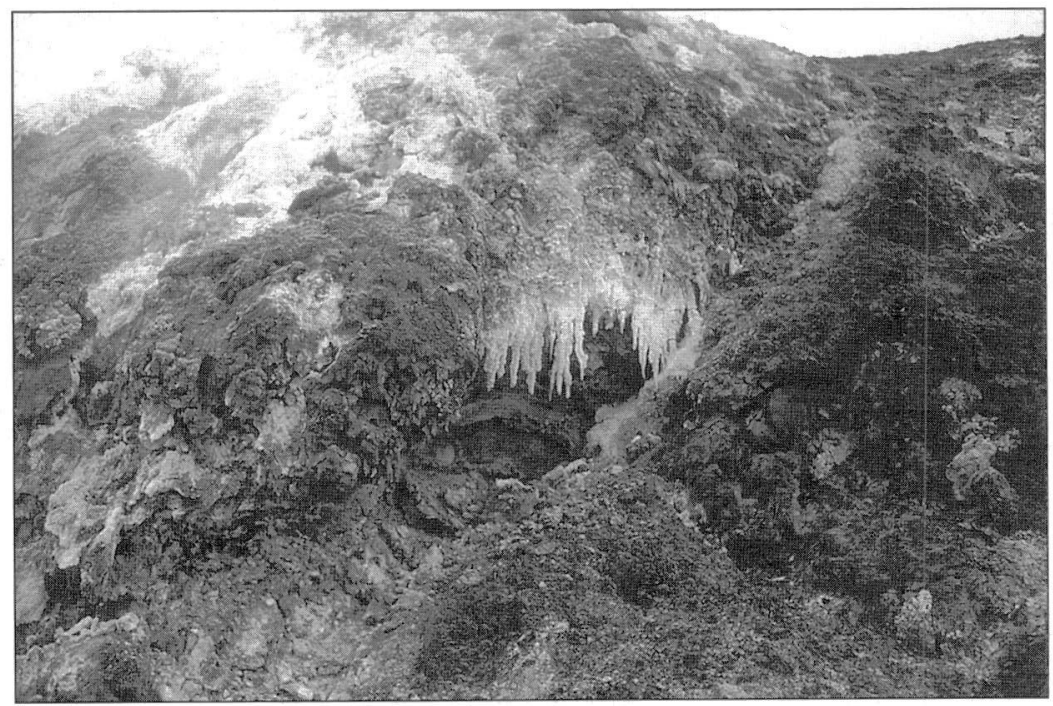

Fig. 8 - Cave in crater wall with stalactites (December 1985) - Photo by Bill Waldron. 
ity, the degree of exposure is considerable and the route very treacherous and slippery. In fact crampons have often been found of great assistance, as the points dig into the smooth solidified ash and lava surfaces and disconcertingly uncontrolled descents can be avoided. There is no surface water on the summit, so porters are normally required to assist in carrying full camping gear, food etc. if the planned visit exceeds one day.

On arrival at the summit on $7^{\text {th }}$ August 1990, the appearance of the crater was much as expected - a well defined roughly oval depression some $400 \times 500 \mathrm{~m}$ in diameter and about 50 to $60 \mathrm{~m}$ deep, with steam venting from some sections (Fig. 10). The crater floor was almost horizontal, and covered by overlying and probably quite recent lava flows with at least four spatter cones, one of which was active and emitting sprays of black lava at intervals (Fig. 11). About $100 \mathrm{~m}$ south of this active cone was what appeared to be the remains of a similar cone, with an adjacent slight mound featuring a prominent irregularly shaped collapse hole at the top, measuring about $10 \mathrm{~m}$ across the widest part (Fig. $12 \& 13$ ). The edges of hole revealed that the surface layer was only about 0.5 to $1 \mathrm{~m}$ thick, and totally unsupported all round the collapse, making its load bearing characteristics distinctly unpredictable. Through the hole could be glimpsed numerous delicate, pale yellow stalactites, descending some $5 \mathrm{~m}$ to the uneven floor of the chamber, which was covered by sections of the collapsed roof. The stalactites were estimated to vary in diameter from less than $1 \mathrm{~cm}$ to 3 to $4 \mathrm{~cm}$, and were highly irregular in cross-sectional area.. This can be more clearly seen in the close up of the cave floor (Fig. 14) which shows some very erratic formations, particularly near the floor with considerable departures from the vertical. In addition some fractured sections can be seen lying horizontally on the ground below. The cave was subsequently given the name of "Hades" by the author. It was difficult to estimate the horizontal extent of the chamber, which was probably 20 to $30 \mathrm{~m}$.

The expedition did not possess any climbing ropes or related equipment, so that descent into the chamber - and more importantly rescue from it - was out of the question. It was thus with considerable trepidation that the author crawled precariously to the edge of the collapse, spreading his weight as widely as possible to avoid an inadvertent descent.. This concern was reinforced by the discovery that extremely hot (estimated to be $>60^{\circ} \mathrm{C}$ ) and moist air (but with no noticeable fumes) was emerging from the pit below. The prospect of being gently poached to death should the roof collapse any further did not appeal, and the situation did not encourage prolonged observation. After taking a series of colour photographs a rapid retreat took place to somewhat firmer ground.

As a large intact cone (Fig. 11) was emitting fresh lava at a height of some $10 \mathrm{~m}$, only about $100 \mathrm{~m}$ away across the crater, there were evidently considerable variations in the lava levels beneath the crater surface, a fact noted by other observers at various times. However the "Hades" stalactites were completely different in size and character to molten lava versions, which are typically a few $\mathrm{cm}$ in length and often curved. Some small isolated stalactites had been observed on Lengai in 1985 (Fig. 8) in 1985, but nothing of similar size and complexity to rival the Hades phenomenon. 


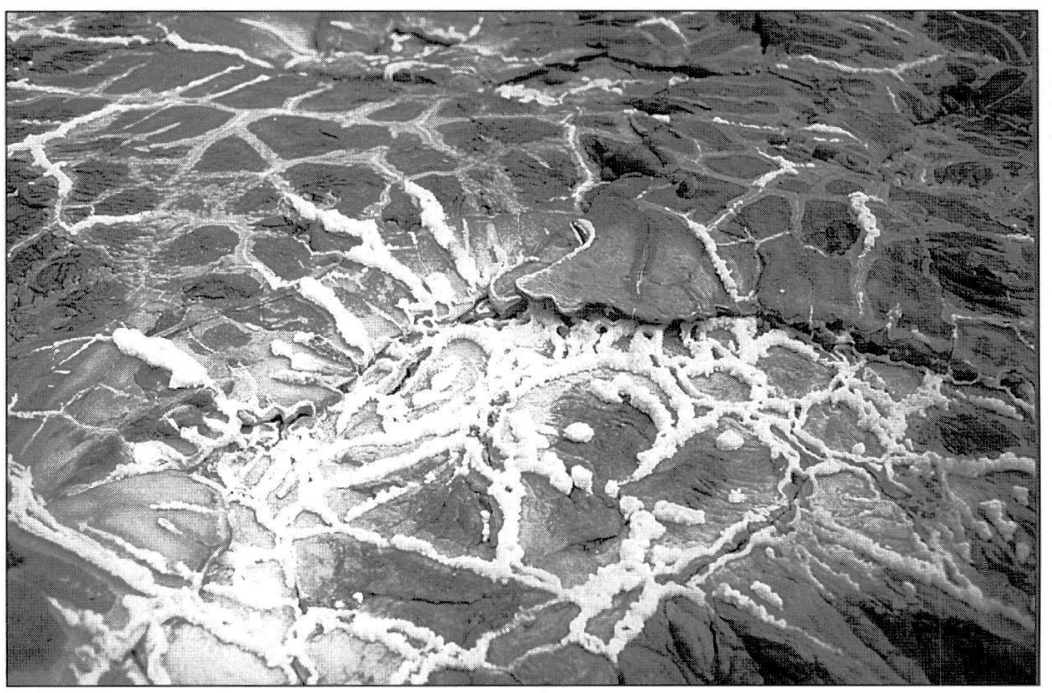

Fig. 9 - Secondary mineral deposits on crater floor (December 1985) - Photo by Bill Waldron.

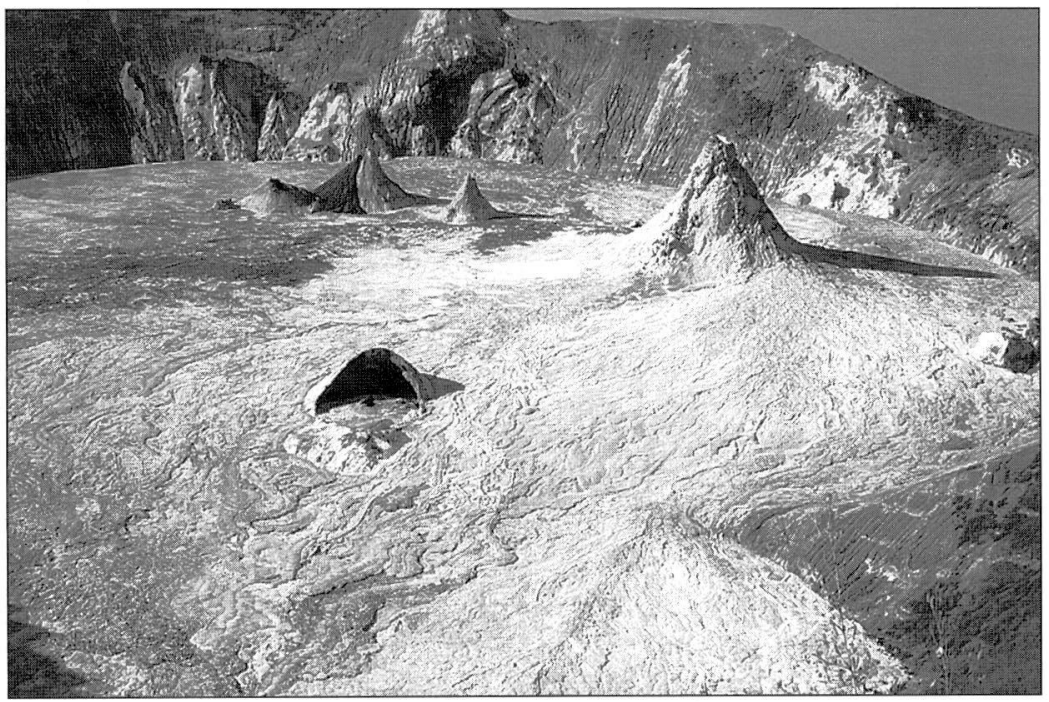

Fig. 10 - General view of crater showing cones and site of Hades cave (left centre) (August 1990). 


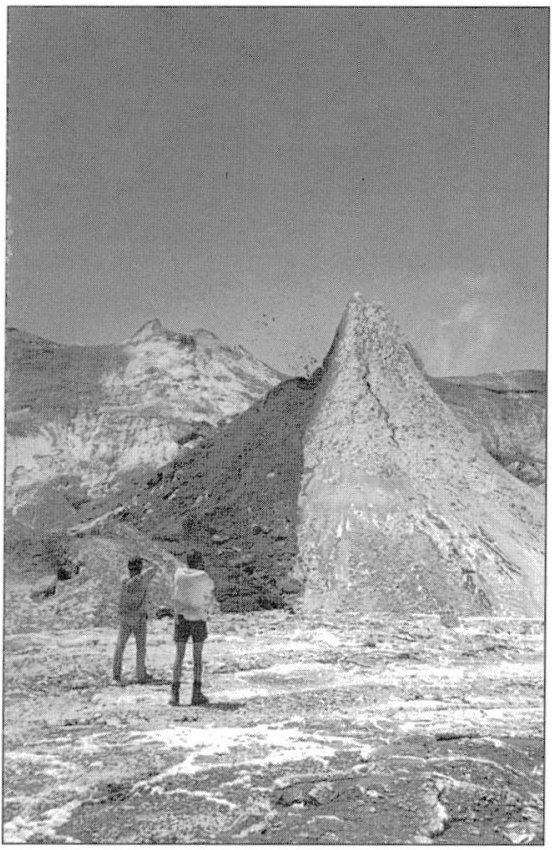

Fig. 11 - Active cone on crater floor (August 1991) Photo by Gordon Davies.

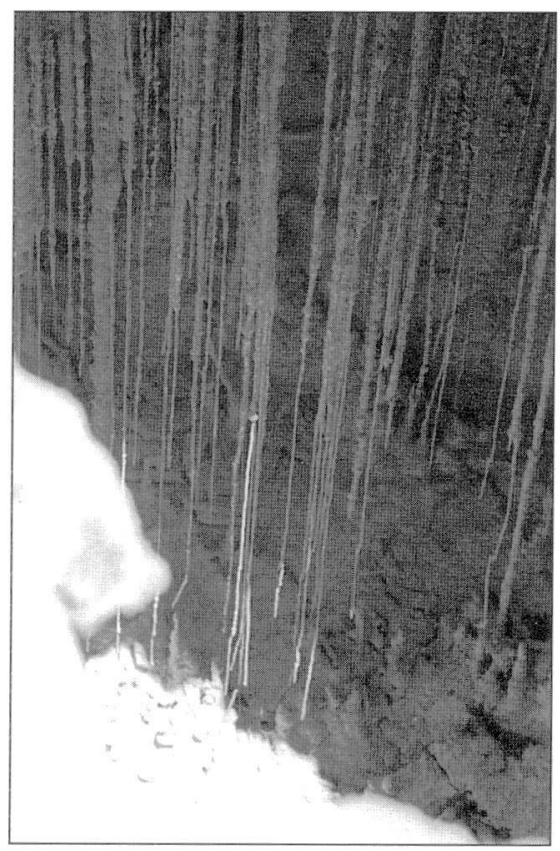

Fig. 13 - Close up view of Hades cáve floor (August 1991) - Photo by Gordon Davies.

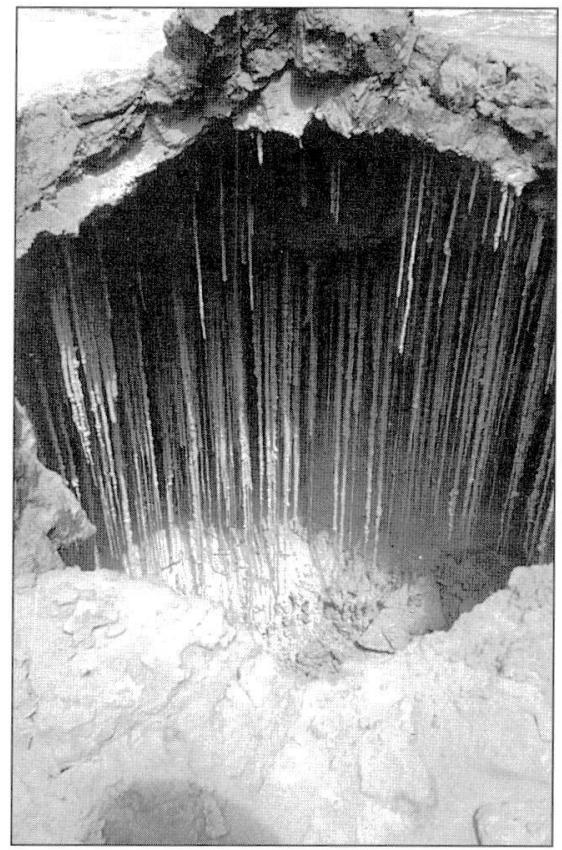

Fig. 12 - View of Hades cave entrance (August 1991) Photo by Gordon Davies.

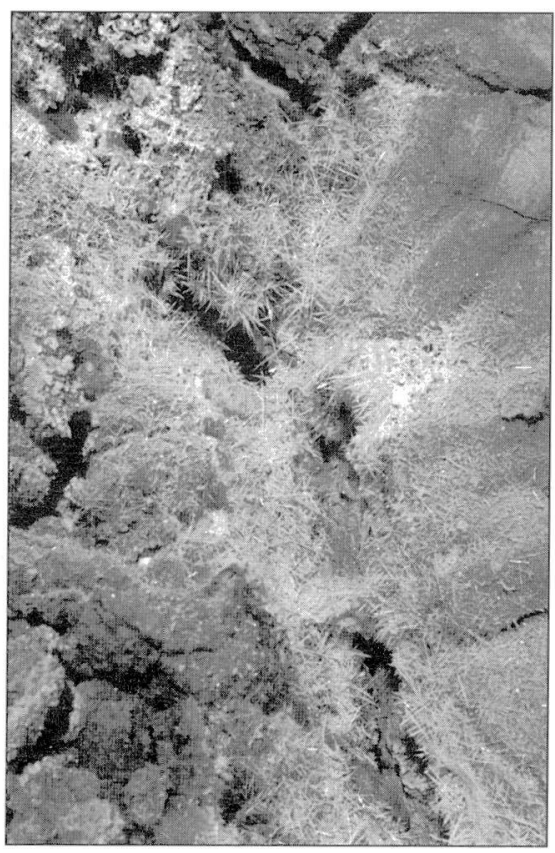

Fig. 14 - Close up of sulphur deposits in crater (August 1991) - Photo by Gordon Davies. 


\section{CONCLUSIONS}

Lengai is situated in a very arid area of the Rift Valley, with an average rainfall in the surrounding countryside of about 25 to $30 \mathrm{~cm}$, much of it precipitated in violent but short lived storms. However Lengai's altitude undoubtedly generates additional precipitation, and it is frequently is covered by a cloud cap even when the surrounding sky is clear.

Whilst no regular recordings have been made, it is reasonable to assume that rainfall on Lengai crater may be quite considerable, especially in the two annual rainy seasons, and certainly there are always numerous stream jets emerging from fissures in and around the crater rim. A storm depositing $7.5 \mathrm{~cm} \mathrm{(3} \mathrm{in)} \mathrm{of} \mathrm{rain} \mathrm{on} \mathrm{the} \mathrm{summit} \mathrm{would}$ result in at least $10,000 \mathrm{~m}^{3}$ of water entering the crater and percolating through cracks and dissolving some of the largely soluble materials of which the lava surface is composed. The author is unable to comment in detail on the possibility of additional water sources, although the highly reactive rocks of the crater floor are also subject to attack from gases and water given off by the magma.

The fact that the crater surface is composed largely of sodium carbonate, and the irregular appearance of the stalactites in Hades and elsewhere, would tend to support the theory that they have a similar chemical composition, and that rain water has played a major role in their formation. The yellow colour is almost certainly sulphur, which does occur elsewhere in the crater (Fig. 14), and might possibly have been deposited on the stalactites by a process of sublimation from subterranean sources. It is likely that the structures were extremely delicate, although no attempt was made to throw in any missiles to test this theory.

The cave itself is likely to have been formed by a lowering in level of molten lava which had originally contributed to the formation of the nearby collapsed cone. This is a very different mechanism to the normal formation of lava caves, although similar cavities with symmetrical, overhanging walls penetrated by a collapse at the top are not unknown, and indeed occur on Suswa, an extinct volcano some $180 \mathrm{~km}$ to the north of Lengai. Here on the southern flanks are a line of 7 raised domes with well-like shafts between 15 and $30 \mathrm{~m}$ deep. Some bell out into chambers with one having a $10 \mathrm{~m}$ passage section leading out at the base of the dome (Simons, 1998)

Due to the relatively intense level of volcanic activity on the summit of Lengai e.g. it was estimated that some $30,000 \mathrm{~m}^{3}$ of fresh lava flowed out onto the crater floor within 14 days in August 1996, it is unlikely that Hades would have survived intact for more than a few months at most.

As so often happens in subterranean structures, the profligate forces of nature create complex and often extremely beautiful secondary mineral deposits, most of which, fortunately, are relatively stable and available for long term study. In the case of Hades, situated at the summit of unique and highly active volcano, the delicate and ephemeral beauty of the formations in this remarkable cave now exist only in the memories of a fortunate few, and in the photographs which recorded this rare phenomenon for posterity.

\section{ACKNOWLEDGEMENTS}

The author wishes to thank delegates attending the $8^{\text {th }}$ International Symposium on Vulcanospeleology held in Nairobi on $7 / 8^{\text {th }}$ February 1998 for the interest they took in the initial presentation concerning Hades and their helpful comments. Thanks are also due to the Hon Chairman of the Cave Exploration Group of East Africa, Jim Simons, for his advice and assistance, and to Bill Waldron (General Manager of Simbarite Ltd, 
Mombasa) who kindly loaned some personal slides and provided a stalactite sample from his 1985 visit to the mountain.

Considerable gratitude is owed to Professor Celia Nyamweru, Department of Anthropology, St Lawrence University, Canton, NY who provided much helpful background information and also commented on a draft of this paper.

\section{REFERENCES}

DAVIES G. J. 1968 Lengai West. Bulletin, Mountain Club of Kenya 67 : pp 4 - 11

DAWSON J.B., H. PINKERTON, G.E. NORTOND. AND M. PYLE 1990 Physicochemical properties of alkali carbonatite lavas: Data from 1988 eruption of Oldoinyo Lengai, Tanzania. Geology 18: pp 260-263.

DAWSON J.B., H. PINKERTON, D. M. PYLE AND C. NYAMWERU. 1994. Eruption of Oldoinyo Lengai, Tanzania: Exceptionally viscous and large carbonatite lava flows and evidence for coexisting silicate and carbonate magmas. Geology, v.22, pp 799 - 802, September

DAWSON J.B., J. KELLER AND C. NYAMWERU 1995 Historic and Recent Eruptive Activity of Oldoinyo Lengai. Carbonatite Volcanism - Oldoinyo Lengai and the Petrogenesis of Natrocarbonatites. Editors; $\mathrm{K}$ Bell and J Keller. Pub Springer-Verlag.

NYAMWERU C. 1997. Changes in the crater of Oldoinyo Lengai: June 1993 - February 1997. Journal of African Earth Sciences, Vol 25, No 1, pp 43-53

RICHARD J.J. 1942 Volcanological Observations in East Africa I - Oldoinyo Lengai. The 1940 to 1941 eruption. Journal E African \& Ugandan Natural History Society 16 (2-3) : 89-108 (19 figs)

SIMONS J. 1998. Volcanic Caves of Kenya - A guide for the 8th International Symposium on Vulcanospeleology. Privately published by J. Simons in Nairobi.

SUTCLIFFE A.J. 1973. Caves of the East African Rift Valley. Trans. Cave Research Group of Great Britain, Vol. 15. No. 1 pp 41-65 February

WALDRON W. Personal communication. (P O Box 90662, Mombasa, Kenya) 